\title{
Edyta Szafranek
}

Uniwersytet Opolski

e-mail: eszafranek@uni.opole.pl

\section{MIEJSKIE OBSZARY FUNKCJONALNE A KSZTAŁTOWANIE SPÓJNOŚCI TERYTORIALNEJ} FUNCTIONAL URBAN AREAS VS. TERRITORIAL COHESION FORMATION

DOI: $10.15611 / \mathrm{pn} .2017 .467 .10$

JEL Classification: O21, R11, R58

Streszczenie: Bieżąca polityka regionalna ma za zadanie kształtować spójność terytorialną, a jedną z jej koncepcji jest funkcjonowanie miejskich obszarów funkcjonalnych. Spójność terytorialna rozumiana jest różnorako. W niniejszym opracowaniu rozpatrywano ją jako: rozwój endogeniczny i policentryczny, wyrównywanie dysproporcji w poziomie rozwoju społeczno-gospodarczego, tworzenie powiązań sieciowych oraz zapewnienie dostępności do usług (głównie wiedzy i infrastruktury). Celem badań jest określenie związku między istotą i praktyką miejskich obszarów funkcjonalnych a kształtowaniem tak pojmowanej spójności terytorialnej. Badania przeprowadzono w układzie regionalnym, na podstawie miejskich obszarów funkcjonalnych południowo-zachodniej części Polski. Jako źródła informacji wykorzystano dokumenty programowe dla badanych obszarów funkcjonalnych, województw i jednostek lokalnych tworzących badane obszary funkcjonalne, a także informacje statystyczne. W pracy prezentowane są wyniki badań przeprowadzonych metodami jakościowymi oraz ilościowymi. Badania wskazują, że działania podejmowane w ramach miejskich obszarów funkcjonalnych nie oddziałują na wyrównywanie dysproporcji w poziomie rozwoju społeczno-gospodarczego oraz dostępie do usług. Spójność terytorialna może być kształtowana przez stymulowanie procesów dyfuzji z obszarów funkcjonalnych i/lub tworzenie sieci ich powiązań. Miejskie obszary funkcjonalne wpisują się w polaryzacyjno-dyfuzyjny model rozwoju regionalnego i aby można było poprawić ich oddziaływanie na spójność terytorialną, wymagane jest ukierunkowanie działań na tworzenie warunków do rozprzestrzeniania się procesów rozwojowych.

Słowa kluczowe: spójność terytorialna, miejskie obszary funkcjonalne, zintegrowane inwestycje terytorialne, południowo-zachodnia Polska, region.

Summary: The main task of the current regional policy is to shape territorial cohesion, and functioning of functional urban areas (FUA) is one of its concepts. The territorial cohesion is understood in all sorts of ways. In this paper it is treated as: endogenous and polycentral development, levelling disproportion in the level of the social-economic development, creating network connections and ensuring the availability of services (mainly knowledge and infrastructure). The main aim of research is to determine the connection between the essence 
and the practice of FUA and forming the territorial cohesion. The research was conducted in the regional layout, based on FUA of the South-West Poland. As sources of information were used programming documents for studied functional areas, provinces, as well as statistical information. The paper presents the effects of research which was performed with the use of qualitative and quantitative methods. Research shows that taken actions in FUA frames do not have an influence for levelling disproportion horizontally of social-economic development and the access to services. The territorial cohesion can be shaped through stimulating diffusion processes from FUA and/or by making the networks of their connections. FUA are connected with polarizing-diffusion model of the regional development. Thus to improve their influence on territorial cohesion, its needed to shape directing actions to make conditions for spreading the development impulse.

Keywords: territorial cohesion, urban functional areas, integrated territorial investments, South-West Poland, region.

\section{Wstęp}

Spójność terytorialna jest jednym z istotnych wymiarów polityki regionalnej Unii Europejskiej i Polski. Jednocześnie na łamach literatury naukowej prowadzona jest dyskusja nad istotą tego pojęcia. Uogólniając, można przyjąć, że podstawą wprowadzenia kwestii spójności terytorialnej do polityki rozwoju, a także do badań naukowych jest zróżnicowanie poziomu rozwoju społeczno-gospodarczego w wymiarze UE, poszczególnych krajów oraz regionów. Zarówno w Unii Europejskiej, jak też Polsce przyjęto, że polityka rozwoju powinna być prowadzona wobec i w ramach obszarów funkcjonalnych, z których w praktyce największe znaczenie mają miejskie obszary funkcjonalne. Przyjęcie obszarów funkcjonalnych jako podstawy polityki rozwoju w założeniu powinno umożliwić osiągnięcie większej efektywności funkcjonowania oraz rozwoju systemów społecznych, gospodarczych i przestrzennych, co powinno się przyczynić do budowania spójności terytorialnej.

Celem podjętych badań jest określenie związku między funkcjonowaniem miejskich obszarów funkcjonalnych a kształtowaniem spójności terytorialnej. Rozważania ukierunkowano na kwestie, które w literaturze przedmiotu wyjaśniane są jako warunki i/lub cele budowania spójności terytorialnej. W tym kontekście analizowano znaczenie miejskich obszarów funkcjonalnych w rozwoju policentrycznym i opartym na wewnętrznych potencjałach i zasobach rozwoju, a także w zakresie dysproporcji regionalnych w poziomie rozwoju społeczno-gospodarczego oraz w odniesieniu do tworzenia powiązań sieciowych.

Badania przeprowadzono na podstawie doświadczeń funkcjonowania miejskich obszarów funkcjonalnych w południowo-zachodniej Polsce (tj. województw opolskiego, dolnośląskiego, lubuskiego). Wybrane jednostki badawcze cechują się już utrwalonym zasięgiem terytorialnym, ukształtowaną strukturą organizacyjną, a także ukończonym i wdrażanym dokumentem programującym strategiczny ich rozwój. Wszystkie wybrane obszary funkcjonalne mają zapewnione finansowanie 
zadań w perspektywie 2014-2020, a co istotne - są względem siebie zróżnicowane. Źródłami informacji wykorzystanymi w toku badań są aktualne dokumenty programujące rozwój każdego z obszarów funkcjonalnych, każdego z regionów oraz wszystkich miast i gmin tworzących badane obszary. W przypadku analiz ilościowych wykorzystano informacje z zasobów statystyki publicznej GUS-u. W odniesieniu do poszczególnych wątków badawczych zastosowano odrębne metody, zarówno ilościowe, jak i jakościowe'. Do rozszerzenia analizy wykorzystano wyniki badań autorskich oraz innych badaczy publikowane na łamach literatury przedmiotu.

\section{Spójność terytorialna - koncepcje i wymiary}

Spójność terytorialna jest określeniem stosowanym powszechnie na gruncie polityki regionalnej oraz badań z zakresu rozwoju regionalnego, jednakże nie zostało ono dotychczas jednoznacznie zdefiniowane. Określenie to znalazło zastosowanie w badaniach naukowych na skutek wprowadzania kolejnych dyrektyw i celów polityki regionalnej UE. Najczęściej jest kojarzone z wyrównywaniem, integracją czy kształtowaniem sprawiedliwości w układzie terytorialnym, co jest związane, z jednej strony, zekonomicznym wymiarem planowania i zarządzania rozwojem, a z drugiej - z koncepcją zintegrowanego podejścia do rozwoju [Szlachta 2011; Greta, Tomczak-Woźniak 2013; Zagrzejewska 2014]. W ramach polityki regionalnej spójność terytorialna pojawiła się w 1997 r. w Traktacie z Amsterdamu, w którym wymiar terytorialny został skojarzony ze zrównoważonym rozwojem [Zagrzejewska 2014, s. 145]. Pierwotnie, niejako w ukrytym sensie, oznaczała ona stan równowagi społeczno-gospodarczej w zróżnicowanej przestrzeni i miała być osiągnięta przez zróżnicowane w wymiarze celów i instrumentów wsparcie finansowe adresowane do regionów. Do kwestii spójności terytorialnej odnoszono się, określając założenia i zasady kwalifikowalności wsparcia działań z funduszy UE [Zaucha i in. 2015, s. 32]. Pojęcie to wraz z upływem czasu w polityce UE ewoluowało, a przede wszystkim ulegał rozszerzeniu jego zakres znaczeniowy [Zaucha i in. 2015, 31-35].

Obecnie w sferze rozwoju regionalnego jest to pojęcie rozpatrywane wieloaspektowo, w zależności od przyjętych założeń polityki rozwoju regionalnego lub podejmowanego problemu badawczego z tego zakresu. W literaturze przedmiotu spójność terytorialna jest pojmowana co najmniej w czterech znaczeniach jako [Zaucha $i$ in. 2015]:

- rozwój endogeniczny i policentryczny,

- tworzenie powiązań sieciowych,

- wyrównywanie międzyregionalnych dysproporcji w poziomie rozwoju społeczno-gospodarczego,

- zapewnienie dostępności do usług i infrastruktury.

1 Zostały wskazane i omówione w kolejnych częściach opracowania. Ze względu na ograniczoną objętość tekstu w artykule przedstawiono tylko wyniki prowadzonych badań, nie omówiono szczegółowo metodyki postępowania. 
Ponadto należy podkreślić, że spójność terytorialna jest traktowana jako cel polityki regionalnej UE, koncepcja zintegrowanego prowadzenia polityki rozwoju jednostek terytorialnych i zapewnienie procesu rozwoju jednostek terytorialnych oraz zaspokojenie potrzeb ich mieszkańców [Szlachta, Zaucha 2010].

W polskiej polityce regionalnej koncepcja spójności terytorialnej znalazła zastosowanie w formułowaniu celów rozwoju regionalnego kraju do 2020 roku. Została wskazana jako drugi cel, pod hasłem „spójność”, i oznaczała: budowanie spójności terytorialnej i przeciwdziałanie marginalizacji obszarów problemowych [Krajowa Strategia... 2010, s. 89]. W tym wypadku spójność terytorialna oznacza stan równowagi, który winien być osiągnięty przez wsparcie obszarów o najtrudniejszych warunkach rozwojowych. Poza tym wprost określonym kontekstem spójność terytorialna jest także wskazana w wypadku dwóch pozostałych celów. Ponadto można przyjąć, że w polityce rozwoju spójność terytorialna jest zdefiniowana dwuwariantowo: jako stan oraz proces. W stanowisku polskiego rządu wobec spójności terytorialnej zaznaczyły się oba warianty, gdyż przyjęto, że „spójność terytorialna to stan rozwoju terytorium, do którego się dąży, w którym procesy wymiany i przepływy w sferze gospodarczej i społecznej przebiegają sprawnie, gwarantując społecznie i gospodarczo efektywną alokację zasobów. Osiąganie spójności terytorialnej powinno być rozumiane jako proces polegający na takim kształtowaniu przestrzeni UE, aby zapewnić najlepszy rozwój unikalnego potencjału poszczególnych terytoriów UE dla osiągnięcia celów rozwojowych UE, w tym spójności społeczno-gospodarczej, poprzez zintegrowane zarządzanie rozwojem" [Stanowisko Rządu... 2009, s. 3].

Odwołując się do przedstawionych koncepcji teoretycznych i wynikających z polityki rozwoju, można przyjąć, że spójność terytorialna stanowi odpowiedź na występujące dysproporcje w rozwoju regionalnym i jest konsekwencją spójności gospodarczej, społecznej i przestrzennej. Jej osiąganie jest uwarunkowane wykorzystaniem dostępnych wewnętrznych zasobów rozwoju: gospodarczych, społecznych i geograficznych, przy jednoczesnym zintegrowanym planowaniu i programowaniu rozwoju.

\section{Miejskie obszary funkcjonalne w polityce rozwoju}

Obszar funkcjonalny w tradycyjnej formule wiąże się z teorią obszarów węzłowych, których granice wyznaczane są na podstawie zasięgu oddziaływania jego centrum. Jako centrum uznaje się ośrodek miejski, który wyróżnia się koncentracją i centralizacją działalności społeczno-gospodarczej, jednocześnie wpływa na integracje całego obszaru funkcjonalnego. Koncepcja ta jest związana $\mathrm{z}$ teorią biegunów wzrostu, wokół których winna się kształtować zintegrowana funkcjonalnie z centrum strefa rozwoju, charakteryzująca się przewagą sił dośrodkowych nad odśrodkowymi [Bronsztejn 1974, s. 11-28; Domański 1993]. Istotne jest, aby w obszarze funkcjonalnym między centrum, a jego otoczeniem zachodziły wzajemne powiąza- 
nia i ciążenia. Jak podkreśla Kuciński [1994], zarówno ośrodek centralny, jak i jego strefa wpływów pełnią ważne, uzupełniające się funkcje, które są zależne od poziomu rozwoju społeczno-gospodarczego oraz jego zróżnicowania funkcjonalno-przestrzennego, wyrażonego dywersyfikacją produkcji i usług.

Obszar funkcjonalny na potrzeby polityki rozwoju został zdefiniowany w Koncepcji Przestrzennego Zagospodarowania Kraju 2030 [2012, s. 178], a także w Krajowej Strategii Rozwoju Regionalnego 2010-2020: regiony, miasta, obszary wiejskie [2010, s. 125] i Krajowej Polityce Miejskiej [2013, s. 163], został też określony ustawowo [Ustawa z dnia 11 lipca 2014 r., art. 7, pkt 1a]. Zgodnie z wymienionymi dokumentami obszar funkcjonalny to zwarty układ przestrzenny składający się z funkcjonalnie powiązanych terenów, charakteryzujących się wspólnymi uwarunkowaniami i przewidywanymi, jednolitymi celami rozwoju, a wyodrębniany jest w celu wykorzystania jego potencjału geograficznego do rozwoju kraju i regionów. Zaznacza się, że funkcjonowanie obszarów funkcjonalnych powinno wynikać z respektowania współpracy podmiotów go tworzących, ich partnerskiego i efektywnego współdziałania - zarówno w układzie pionowym, jak i poziomym [Krajowa Polityka... 2014, s. 125]. Zgodnie z założeniami bieżącej polityki szczególnym adresatem rozwoju zmierzającego do osiągnięcia spójności terytorialnej są miasta i tereny podlegające procesom urbanizacji [Krajowa Polityka... 2014, s. 8-9], a zatem tzw. miejskie obszary funkcjonalne. Grupę miejskich obszarów funkcjonalnych w Polsce podzielono na 4 typy, zależne od pozycji ośrodka miejskiego w hierarchii funkcjonalnej systemu osadniczego. Wyróżniono obszary funkcjonalne miast: wojewódzkich, w tym metropolitalnych, regionalnych ${ }^{2}$, subregionalnych ${ }^{3}$ i lokalnych ${ }^{4}$ [Koncepcja Przestrzennego... 2012, s. 185-210]. Najważniejszą rolę, zarówno w polityce miejskiej, jak i regionalnej, odgrywają obszary funkcjonalne miast wojewódzkich oraz regionalnych. Jak stwierdza Kuźnik [2015, s. 12], miejskie obszary funkcjonalne to nie tylko obszary silnych, dośrodkowych powiązań między tworzącymi je jednostkami osadniczymi. Zdaniem cytowanego autora należy je rozpatrywać jako obszary, które łączą wyzwania rozwojowe rangi ponadlokalnej, wspólne dla wielu jednostek osadniczych tworzących obszar funkcjonalny, a także posiadają duży potencjał współdziałania wyrażający się procesami samoorganizacji oraz instytucjami znamionującymi kooperacyjne zarządzanie. Autor podkreśla, że miejskich obszarów funkcjonalnych nie należy traktować jako jednostki, które łączy wspólnota problemów do rozwiązania lecz raczej wspólnota wyzwań, co do których powinny być podjęte strategiczne ustalenia. Dodaje także, że wyzwania te po-

2 Miast niepełniących funkcji ośrodków wojewódzkich, ale pełniących ważne funkcje administracyjne, gospodarcze, społeczne, a także posiadających duży potencjał dla rozwoju z perspektywy celów polityki przestrzennego zagospodarowania kraju.

3 Miast od 50 do 100 tys. mieszkańców, pełniących ważne funkcje w rozwoju społeczno-gospodarczym i przestrzennym województw.

${ }_{4}$ Miast poniżej 50 tys. mieszkańców, koncentrujących funkcje gospodarcze i służących obszarom wiejskim zapleczem usługowym. 
winny mieć charakter ponadlokalny, który trudno jest rozwiązać przez jedną gminę (np. inwestycje z zakresu gospodarki niskoemisyjnej). Drugi wymiar funkcjonowania miejskich obszarów funkcjonalnych sprowadza się do wykorzystania i tworzenia instytucji współdziałania oraz realizowania wspólnych projektów rozwojowych. Kuźnik [2015, s. 12] podkreśla, że dla miejskich obszarów funkcjonalnych warto generować rozwiązania strategiczne i przeznaczać środki rozwojowe polityki miejskiej.

Jednym z kluczowych instrumentów odnoszącym się do polityki rozwoju obszarów funkcjonalnych są Zintegrowane Inwestycje Terytorialne (ZIT). Zgodnie z założeniami polityki regionalnej UE i Polski jest to instrument dedykowany przede wszystkim zrównoważonemu rozwojowi obszarów miejskich [Zintegrowane... 2015, s. 4; Rozporządzenie Parlamentu..., art. 7, p. 2]. Przyjęcie miejskich obszarów funkcjonalnych jako głównych adresatów realizacji ZIT wynika z założeń polityki regionalnej UE wskazujących, że miasta i ich sieci mają się stać ogniwami rozwoju społeczno-gospodarczego krajów oraz regionów. W praktyce polityki regionalnej ZIT są realizowane w przypadku obszarów funkcjonalnych, ukształtowanych wokół miast wojewódzkich i regionalnych. Wynika to z uprzywilejowanego sposobu finansowania zadań z zakresu ZIT przez zarezerwowanie środków na ten cel w regionalnych programach operacyjnych na lata 2014-2020 [Szafranek 2015a, 2015b; Płażek 2015]. Sytuacja ta warunkowana jest zakładaną współzależnością wdrażania ZIT i pozytywnych zmian, które powinny się uzewnętrznić w kształtowaniu i realizacji sfery formalno-organizacyjnej poszczególnych obszarów funkcjonalnych i jednostek je tworzących oraz województw. W tym zakresie podkreśla się, że realizacja ZIT ma przede wszystkim na celu [Zintegrowane... 2015, s. 5]:

- promowanie partnerskiego modelu współpracy różnych jednostek administracyjnych w miejskich obszarach funkcjonalnych,

- kształtowanie umiejętności realizacji zintegrowanych projektów odpowiadających w sposób kompleksowy na potrzeby i problemy miast oraz ich obszarów funkcjonalnych,

- zwiększenie wpływu miast i ich obszarów funkcjonalnych na kształt i sposób realizacji działań w ramach polityki spójności.

Warunkami realizacji ZIT na obszarach funkcjonalnych są: zawiązanie zinstytucjonalizowanej formy partnerstwa ${ }^{5}$, przygotowanie strategii ZIT, podpisanie regionalnego porozumienia do realizacji ZIT ${ }^{6}$, zawarcie stosownych zapisów w re-

5 Jako potencjalne formy partnerstw tworzące związki ZIT dla obszarów funkcjonalnych wskazane zostały: związek międzygminny lub powiatowy, stowarzyszenie jednostek samorządu terytorialnego, porozumienie międzygminne, spółka założona wspólnie przez jednostki samorządu terytorialnego [Programowanie perspektywy... 2015, s. 217].

${ }_{6}$ Zawierane jest w województwie między związkiem ZIT a Instytucją Zarządzającą Regionalnym Programem Operacyjnym. 
gionalnym programie operacyjnym ${ }^{7}$ [Ustawa o zasadach realizacji...]. Za kluczowe warunki realizacji ZIT należy uznać przyjęcie zinstytucjonalizowanej formy partnerstwa oraz przygotowanie strategii ZIT. Konsekwencją tych warunków jest fakt, iż to w dużym stopniu wola przynależności wyrażona przez władze poszczególnych miast i gmin miała wpływ na kształt obszarów funkcjonalnych będących jednostkami oddziaływania polityki regionalnej i miejskiej. Nie były to tylko uwarunkowania geograficzne czy społeczno-gospodarcze, decydujące o zasięgu i sile ciążeń i powiązań funkcjonalnych. W konsekwencji geografia miejskich obszarów funkcjonalnych w realizowanej polityce rozwoju jest zatem nieco inna niż zakładana w Koncepcji Przestrzennego Zagospodarowania Kraju 2030 [Heffner, Gibas 2015; Noworól 2015; Szafranek 2015b].

\section{Miejskie obszary funkcjonalne w południowo-zachodniej Polsce}

Ze względu na istotną rolę miast i obszarów funkcjonalnych w polityce regionalnej Polski wyznaczono miejskie obszary funkcjonalne we wszystkich województwach. W prezentowanych badaniach wykorzystano jako podstawę analizy miejskie obszary funkcjonalne województw południowo-zachodniej Polski. Łącznie jest to sześć obszarów funkcjonalnych, z których trzy są ukształtowane wokół ośrodka wojewódzkiego i trzy wokół ośrodków regionalnych. Do badania zakwalifikowano te obszary funkcjonalne, dla których działania w zakresie ZIT zostały ujęte w regionalnych programach operacyjnych poszczególnych województw na lata 2014-2020. Sytuacja ta niejako gwarantuje realizację zadań przyjętych w strategiach ZIT dla tych obszarów funkcjonalnych. Wykaz obszarów funkcjonalnych objętych badaniem wraz z podstawowymi ich cechami przedstawiono $\mathrm{w}$ tab. 1 , natomiast ich zasięg przestrzenny na rys. 1 i $2^{8}$.

Badane obszary funkcjonalne są zróżnicowane pod względem zarówno typu, jak też potencjału ludnościowego i skali finansowania. Dane ilościowe wskazują, że miejskie obszary funkcjonalne odgrywają wiodącą rolę w województwie, największą w dolnośląskim. Potwierdza to ich największy potencjał ludnościowy, liczący w skali regionu niemal 48\% ludności, a także największa skala finansowania w ramach regionalnego programu operacyjnego, stanowiąca prawie $27 \%$ ogółu budżetu. Szczególną rolę w tym zakresie odgrywa Wrocławski Obszar Metropolitalny. Spośród dolnośląskich miejskich obszarów funkcjonalnych wyróżnia się także OF Wałbrzycha - Aglomeracja Wałbrzyska. Jest to jeden z pierwszych utworzonych jeszcze w 2013 r. obszarów funkcjonalnych ośrodka regionalnego, z przyjętą jako pierwszą strategią ZIT. W województwie lubuskim ustanowiono dla obu ośrodków

${ }^{7}$ Realizacja ZIT w ramach RPO odbywa się przez wyodrębnienie dedykowanych działań lub poddziałań w ramach co najmniej dwóch osi priorytetowych RPO finansowanych z co najmniej dwóch celów tematycznych i funduszy polityki spójności.

8 Zasięg oznaczono szrafurą kreskową. 
regionalnych obszary funkcjonalne, które charakteryzują się podobnym potencjałem ludnościowym, finansowym, a także zasięgiem przestrzennym. Zarówno Zielona Góra, jak i Gorzów Wielkopolski skupiają w zasięgu obszaru funkcjonalnego swoje sąsiednie gminy (odpowiednio 5 i 6 jednostek). Obszar funkcjonalny Opola - Aglomeracja Opolska - stanowi w swoim regionie najważniejszy obszar wsparcia, a potencjałem jest podobny do Aglomeracji Wałbrzycha. W stosunku do potencjału ludnościowego charakteryzuje się relatywnie małym poziomem finansowania. Pod względem struktury wsparcia ze środków UE w każdym z rozpatrywanych obszarów dominującą część stanowią środki Europejskiego Funduszu Rozwoju Regionalnego (EFRR). Wskazuje to na przewagę planowanych zadań inwestycyjnych o charakterze infrastrukturalnym, a mniejszy udział wsparcia dla tzw. projektów „miękkich”.

Tabela 1. Miejskie obszary funkcjonalne Polski południowo-zachodniej, którym zapewniono finansowanie ZIT w ramach regionalnych programów operacyjnych na lata 2014-2020

\begin{tabular}{|c|c|c|c|c|c|c|c|c|}
\hline \multirow{2}{*}{ Województwo } & \multirow{2}{*}{$\begin{array}{c}\text { Obszary } \\
\text { funkcjonalne }\end{array}$} & \multicolumn{2}{|c|}{$\begin{array}{c}\text { Ludność } \\
\text { obszarów } \\
\text { funkcjonalnych }\end{array}$} & \multicolumn{3}{|c|}{$\begin{array}{l}\text { Wartość przeznaczona } \\
\text { na finansowanie ZIT }\end{array}$} & \multicolumn{2}{|c|}{ \% ze źródeł } \\
\hline & & liczba & $\%$ & $\begin{array}{l}\text { ogółem } \\
\text { (EUR) }\end{array}$ & $\begin{array}{c}\% \\
\mathrm{RPO}\end{array}$ & $\begin{array}{c}\text { na } 1 \\
\text { mieszkańca } \\
\text { OF (EUR) }\end{array}$ & EFRR & EFS \\
\hline Dolnośląskie & $\begin{array}{l}\text { Wrocławski } \\
\text { OM, OF } \\
\text { Wałbrzycha, } \\
\text { OF Jeleniej } \\
\text { Góry }\end{array}$ & 1394020 & 47,9 & 607075000 & 26,95 & 435,49 & 80,55 & 19,45 \\
\hline Lubuskie & $\begin{array}{l}\text { MOF dla } \\
\text { miasta Go- } \\
\text { rzów Wlkp., } \\
\text { MOF dla } \\
\text { miasta Zielo- } \\
\text { na Góra }\end{array}$ & 119001 & 26,6 & 107628028 & 11,87 & 904,43 & 82,98 & 17,02 \\
\hline Opolskie & Opolski OF & 337383 & 33,6 & 71400000 & 7,56 & 211,63 & 79,69 & 20,31 \\
\hline
\end{tabular}

Źródło: opracowanie własne.

Kluczowe jednak dla realizacji spójności terytorialnej nie są sygnalizowane dane ilościowe o obszarach funkcjonalnych, lecz rodzaj podejmowanych działań, sposób ich realizacji i funkcjonowania tych jednostek terytorialnych. W dalszej części opracowania przedstawione zostaną wybrane aspekty funkcjonowania miejskich obszarów funkcjonalnych w kontekście spójności terytorialnej. 


\section{Miejskie obszary funkcjonalne a policentryczność i integracja wyzwań rozwoju}

Według założeń polityki regionalnej spójność terytorialna ma być kształtowana m.in. przez policentryczny rozwój miast. Wyodrębnienie i wprowadzenie miejskich obszarów funkcjonalnych do praktyki rozwoju kraju i regionów można zatem uznać za bezpośrednią odpowiedź na wyzwanie dotyczące spójności terytorialnej. Należy podkreślić, że nie chodzi tu o zagęszczanie sieci miejskiej, lecz o budowanie silnych ośrodków miejskich. Zadaniem dla polityki regionalnej i miejskiej jest oddziaływanie na rozwój funkcji wielkomiejskich, a w tym metropolitalnych. Jak stwierdza Polski [2015, s. 76], budowanie policentryczności powinno obejmować także poprawę standardów urbanistycznych mniejszych miast, tak aby umożliwić ich otwarcie na rozwój. Jako kolejny kierunek wskazuje się oddziaływanie na przekształcenia strukturalne w obrębie miast i otwarcie ich na nowych użytkowników, w tym na przedsiębiorczość, mieszkalnictwo, usługi publiczne (instytucje i organizacje społeczne) oraz przyjezdnych. Kierunki działań na rzecz kształtowania policentryczności znajdują zastosowanie $w$ idei powołania miejskich obszarów funkcjonalnych oraz przyjęcia ZIT jako instrumentu ich rozwoju.

Jeżeli przyjąć, że spójność terytorialna ma się wyrażać rozwojem opartym na zasobach i potencjałach wewnętrznych, to należy zwrócić uwagę, czy strategie ZIT uwzględniają taką właściwość. W tym celu przeprowadzono analizę zgodności celów wdrażania ZIT w badanych obszarach funkcjonalnych z celami (lub priorytetami) rozwoju gmin tworzących dany obszar funkcjonalny. Podstawą oceny spójności rozpatrywanych celów były macierze cross-impact, w których dla każdego $\mathrm{z}$ obszarów funkcjonalnych zestawiono cele ich rozwoju z celami rozwoju jednostek lokalnych tworzących dany obszar funkcjonalny ${ }^{9}$. Stwierdzano fakt zgodności porównywanych celów, jeśli w strategiach rozwoju jednostek lokalnych zawarte były cele zbieżne z celami rozwoju obszaru funkcjonalnego. Wyniki przeprowadzonej analizy wskazują na zróżnicowany stopień zgodności celów. Zakres udziału gmin tworzących obszar funkcjonalny, które miały cel własnego rozwoju zgodny z celem strategii ZIT, zawierał się w przedziale od $12,5 \%$ do $95,3 \%$. Wyższy stopień zgodności celów dotyczył obszarów funkcjonalnych złożonych z mniejszej liczby jednostek samorządowych. Znamienne jest jednak, że część gmin w swoich dokumentach strategicznych nie miała takich celów rozwoju, które zostały określone na poziomie obszaru funkcjonalnego. Sytuacja ta może wskazywać na nieuwzględnianie potrzeb i potencjałów rozwoju tych gmin w strategicznym programowaniu rozwoju obszaru funkcjonalnego. Rozpatrując zgodność programowania rozwoju obszarów

9 Ze względu na różną metodologię opracowania strategii rozwoju poszczególnych jednostek terytorialnych i samorządowych przyjęto jako podstawę porównania rozpatrywanych celów maksymalnie ich drugi stopień szczegółowości (były to cele ogólne lub strategiczne/szczegółowe). W sytuacji nieposiadania aktualnej strategii rozwoju przez określoną gminę wykorzystano plan rozwoju lokalnego. 
funkcjonalnych i gmin je tworzących, przeprowadzono także analizę spójności celów w wymiarze dziedzinowym oraz ze względu na przestrzenny typ inwestycji. Biorąc pod uwagę spójność dziedzinową, wskazano trzy poziomy zgodności: wysoki (powyżej 70\%), przeciętny (35-69\%) i niski (poniżej 35\%). Wysokim stopniem zgodności cechowały się cele dotyczące rozwoju gospodarczego, w tym m.in. z zakresu poprawy aktywności ekonomicznej i zawodowej, modernizacji struktury gospodarczej oraz pozyskiwania nowych inwestycji. Przeciętny stopień zgodności dotyczył celów odnoszących się do kształtowania warunków rozwoju społecznego, a w szczególności budowy lub/i odnowy infrastruktury społecznej i technicznej, głównie w sferze usług publicznych, w tym w edukacji, ochronie zdrowia i gospodarce komunalnej. Ostatnia grupa celów, charakteryzująca się niskim stopniem zgodności, odnosiła się do nowych wyzwań polityki ukierunkowanej terytorialnie, takich jak gospodarka niskoemisyjna i kształtowanie zintegrowanego partnerstwa na rzecz rozwoju. Uzyskany rezultat można uznać za oczekiwany, gdyż strategie rozwoju gmin zostały opracowane przed przygotowaniem strategii ZIT dla obszarów funkcjonalnych. Nowe wyzwania nie były zatem wskazywane w dokumentach strategicznego rozwoju na poziomie lokalnym. Wyniki potwierdzają tezę Kuźnika [2015], że obszary funkcjonalne powinny przejawiać integrację wspólnoty dla nowych wyzwań rozwojowych. W tym kontekście trzeba jednak zaznaczyć, że minimalizowanie zakresu wspólnych działań dotyczących wewnętrznych potrzeb rozwojowych nie zapewnia w pełni wewnętrznej spójności terytorialnej tych obszarów.

$\mathrm{W}$ odniesieniu natomiast do charakteru przestrzennego realizacji zakładanych zadań wysokim stopniem zgodności charakteryzowały się zadania o zasięgu powierzchniowym, skoncentrowanym przestrzennie, np. powstawanie nowych stref inwestycyjnych, natomiast przeciętnym zadania o charakterze punktowym i rozproszonym bądź liniowym - sieciowym. Sytuacja ta powoduje, że większa część gmin tworzących dany obszar funkcjonalny nie będzie bezpośrednio partycypowała w realizacji przyjętego celu, gdyż najczęściej jako miejsce inwestycji wskazywany jest ośrodek centralny. Druga grupa celów odnosi się do zadań, które dotyczą budowy lub modernizacji infrastruktury o charakterze sieciowym, takich jak sieć komunikacyjna czy wodno-kanalizacyjna. W realizacji tego typu zadań partycypować może w sposób bezpośredni kilka gmin, dlatego rzeczywista spójność powinna być wysoka.

Jako rozszerzenie analizy spójności celów rozwoju obszarów funkcjonalnych w kształtowaniu spójności terytorialnej przeprowadzono porównanie celów rozwoju obszarów funkcjonalnych z celami rozwoju województw, w których są one położone. W tym zakresie dostrzega się ścisłe podobieństwo. Dowodzi to, że wyznacznikiem formułowania celów rozwojowych dla obszarów funkcjonalnych są zapisy regionalnych programów operacyjnych poszczególnych województw, w których zgodnie z wytycznymi ministerialnymi wskazano zasady i możliwości finansowania zadań dla obszarów funkcjonalnych. 


\section{Miejskie obszary funkcjonalne a dysproporcje regionalne}

Punktem wyjścia w ocenie dysproporcji rozwojowych między obszarami funkcjonalnymi a pozostałą częścią województw było określenie poziomu rozwoju społeczno-gospodarczego. Badania przeprowadzono w ujęciu statycznym dla roku 2014, a także dynamicznym obejmującym okres $2004-2014^{10}$, wykorzystując metodę taksonomicznej odległości od wzorca Hellwiga [1968]. Do określenia stopnia zróżnicowania poziomu rozwoju wyznaczono wzorzec abstrakcyjny dla każdego z województw odrębnie, gdyż charakteryzują się one istotnym zróżnicowaniem uwarunkowań rozwoju. W odniesieniu do wyznaczonego wzorca obliczono odległość każdej jednostki poziomu lokalnego (miasta i gminy), na podstawie której ustalono stopień podobieństwa do jednostki o wyznaczonym wzorcowym poziomie rozwoju społeczno-gospodarczego. Uzyskane miary odległości pogrupowano w cztery kategorie, wykorzystując zasadę równej długości przedziałów klasowych. Diagnozę stanu zróżnicowania poziomu rozwoju społeczno-gospodarczego w 2014 r. przedstawiono na rys. 1, a tendencję zmian w latach 2004-2014 na rys. $2^{11}$.

Porównując stan i tendencję zmian w zakresie zróżnicowania poziomu rozwoju społeczno-gospodarczego w przestrzeni analizowanych regionów, zauważa się trwałą dominację miast nad obszarami je otaczającymi. W każdym województwie, dla którego wyznaczono odrębny wzorzec rozwoju, jednostką najbardziej do niego podobną był ośrodek wojewódzki. W przypadku ujęcia statycznego, czyli dla roku 2014, sytuacja ta jest wyraźnie widoczna, także w kontekście relacji między poziomem rozwoju ośrodka centralnego a pozostałą częścią obszaru funkcjonalnego. W odniesieniu do wszystkich obszarów funkcjonalnych, poza OF Zielonej Góry, zaznacza się także wyraźna dysproporcja między ośrodkiem centralnym a pozostałą częścią obszaru funkcjonalnego. Ujęcie dynamiczne wskazuje, że sytuacja w bezpośrednim otoczeniu miast centralnych się poprawia, gdyż cześć gmin położonych w tym obszarze podnosi stopień podobieństwa. Jest to widoczne głównie w przypadku obszaru funkcjonalnego Wrocławia i Opola, a także Wałbrzycha. Jednakże mimo zarysowującej się tendencji progresywnej w poziomie rozwoju

${ }^{10} \mathrm{~W}$ obu podejściach badawczych wykorzystano zmienne, tj. wskaźnik gęstości zaludnienia, wskaźnik obciążenia demograficznego; wskaźnik przyrostu naturalnego; odsetek wymeldowań do miast; wskaźnik salda migracji; liczbę podmiotów wpisanych do rejestru REGON na 10 tys. ludności; udział nowo zarejestrowanych podmiotów sektora kreatywnego w liczbie nowo zarejestrowanych podmiotów ogółem; stopę bezrobocia; udział podmiotów gospodarki narodowej w sekcjach J-R (wg PKD 2007) w łącznej liczbie podmiotów gospodarki narodowej w rejestrze Regon; liczbę budynków biurowych oraz handlowo-usługowych oddanych do użytku na 1000 mieszkańców. Ostateczna grupa mierników była zależna przede wszystkim od możliwości uzyskania odpowiednich danych statystycznych w analizowanych układach przestrzennych oraz kryteriów statystycznych kwalifikowania zmiennych diagnostycznych.

${ }^{11}$ Dla każdego województwa wyznaczono odrębny wzorzec rozwoju; mapy obrazują zróżnicowanie poziomu rozwoju w obrębie poszczególnych regionów (nie należy porównywać poziomu rozwoju międzyregionalnego). 


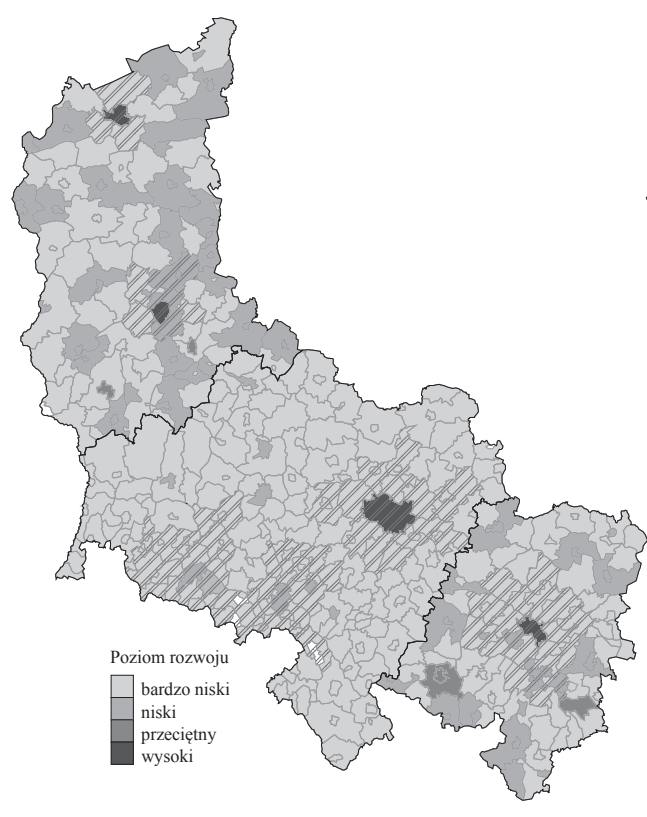

Rys. 1. Zróżnicowanie poziomu rozwoju społeczno-gospodarczego w układzie jednostek lokalnych w województwach południowo-zachodniej Polski w roku 2014

Źródło: opracowanie własne.

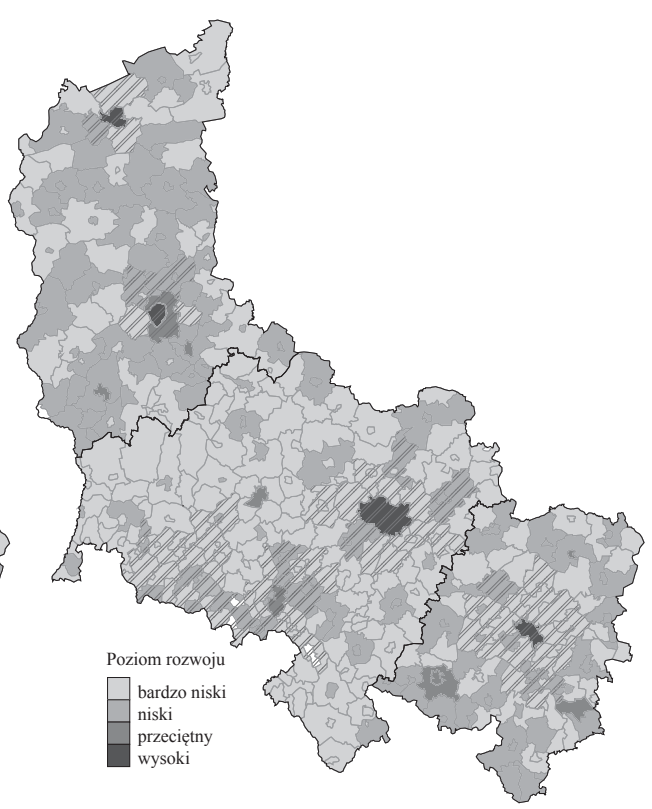

Rys. 2. Zróżnicowanie poziomu rozwoju społeczno-gospodarczego w układzie jednostek lokalnych w województwach południowo-zachodniej Polski w latach 2004-2014

Źródło: opracowanie własne.

społeczno-gospodarczego miast i gmin tworzących obszary funkcjonalne, dysproporcje nadal się utrzymują. Zróżnicowane uwarunkowania rozwoju każdego z województw wpływają na nieco inną charakterystykę rozkładu poziomu rozwoju społeczno-gospodarczego, jednak znaczenie ośrodka dominującego jest wyraźne. Uzyskane wyniki potwierdzają dotychczasowe ustalenia wielu badaczy, które wskazują, że kształtowany typ relacji w układzie silny ośrodek miejski - jego otoczenie prowadzi do postępującej dywergencji tych dwóch jednostek terytorialnych [Adamczyk-Łojewska 2011; Smętowski 2010]. Podobna sytuacja dotyczy atrakcyjności warunków zamieszkiwania w strefach obszarów funkcjonalnych, które są pochodną poziomu rozwoju społeczno-gospodarczego. Z badań Szafranek [2016] wynika, że warunki zamieszkiwania, rozumiane jako tzw. środowisko mieszkaniowe, na które składają się cechy opisujące zarówno stan i wyposażenie mieszkań, jak też budynków mieszkalnych i terenów mieszkaniowych, są zależne od pozycji i roli ośrodka centralnego danego obszaru funkcjonalnego w przestrzeni regionalnej i ponadregionalnej. Ocena całości warunków zamieszkiwania dowodzi, że najwyższy poziom występuje w obszarach ukształtowanych wokół ośrodków metropolitalnych i dużych aglomeracji. Wynika to przede wszystkim z koncentracji w tych obszarach 
zarówno zabudowy mieszkaniowej, jak też jej towarzyszącej, pełniącej funkcje gospodarcze i społeczne. W większości miejskich obszarów funkcjonalnych wyższy poziom warunków zamieszkania występuje na terenie miast centralnych niż stref zewnętrznych. Większy stopień równowagi w zakresie ukształtowania warunków zamieszkania między obiema porównywanymi strefami ma miejsce w przypadku obszarów funkcjonalnych ukształtowanych wokół ośrodków o niższym poziomie rozwoju [Szafranek 2016, s. 160-162].

Analiza dysproporcji regionalnych w poziomie rozwoju społeczno-gospodarczego, a także warunków zamieszkiwania wskazuje, że miejskie obszary funkcjonalne i polityka prowadzona w stosunku do nich mogą się przełożyć na kształtowanie spójności terytorialnej tylko w przypadku stworzenia warunków do procesu dyfuzji. Zaistniała rozbieżność stopnia rozwoju jednostek przy braku aktywnej polityki regionalnej, ukierunkowanej na tworzenie infrastrukturalnych, instytucjonalnych czy społecznych kanałów rozprzestrzeniania impulsów rozwojowych na tereny otoczenia może skutkować pogłębiającą się dywergencją wewnątrzregionalną.

\section{Miejskie obszary funkcjonalne a powiązania sieciowe}

Kolejnym ujęciem identyfikowanym z kształtowaniem spójności terytorialnej jest tworzenie powiązań sieciowych. Należy je rozpatrywać jako powiązania funkcjonalno-przestrzenne zachodzące wukładzie regionalnym i ponadregionalnym, a także w obrębie konkretnych obszarów funkcjonalnych. Wprowadzenie wsparcia dla mechanizmów rozwoju współpracy i sieciowania w stosunku do miejskich obszarów funkcjonalnych ma za zadanie budowanie ponadregionalnych powiązań, ale może się także przyczynić do niwelowania skali dywergencji regionalnej. Zgodnie z tezą Sagan [2009] powiązania sieciowe o charakterze ponadregionalnym zwiększają szanse rozwojowe obszarów miejskich. Jednocześnie należy podkreślić, że brak powiązań silnego ośrodka miejskiego z bezpośrednim otoczeniem prowadzi do peryferyzacji całego regionu. Miejskie obszary funkcjonalne z założenia cechuje znaczna siła wewnętrznych powiązań między obszarem centralnym a jego strefą zewnętrzną. Budowane w ramach obszaru funkcjonalnego relacje między obiema strefami sprzyjają poszerzaniu zakresu potencjałów wykorzystywanych na rzecz rozwoju gospodarczego, a równocześnie wspierają rozwój mniejszych ośrodków [Kmieć, Wrana 2011]. Można zatem założyć, że funkcjonowanie miejskich obszarów funkcjonalnych przyczynia się do wzmacniania mechanizmów dyfuzji, a także budowania silniejszych struktur gospodarczych opierających się na relacjach partnerstwa. Zatem z punktu widzenia kształtowania spójności terytorialnej istotne jest występowanie powiązań sieciowych miejskich obszarów funkcjonalnych zarówno w wymiarze ponadregionalnym, jak też wewnętrznym. Miejskie obszary funkcjonalne stanowią bieguny rozwoju regionów, dlatego regionalna integracja powinna dążyć do zacieśniania powiązań funkcjonalnych między tymi ośrodkami a pozostałymi, w tym przede wszystkim usytuowanymi niżej w sieci hierarchicznej. Sytu- 
acja taka powinna usprawnić zarówno zdolność transferu zasobów z regionu do centrum, jak i możliwości rozprowadzania zasobów koniecznych do rozwoju lokalnego z centrum do regionu [Heffner 2011, s. 13].

Powiązania sieciowe zachodzące między miastami wskazują na silne ich zależności od pozycji miasta w hierarchii funkcjonalnej w systemie osadniczym oraz od ich potencjału ludnościowego. Ponadto istotnym warunkiem kształtowania powiązań sieciowych jest sprawny system komunikacyjny obejmujący zarówno infrastrukturę transportową, jak i łączności. Całościowa analiza oddziaływań ośrodków będących centrami miejskich obszarów funkcjonalnych wskazuje, że wszystkie miasta południowo-zachodniej Polski mają wąskie, ale ściśle połączone strefy bezpośrednich powiązań. Jedynie Wrocław wskazuje na większy zakres oddziaływania, mający charakter ponadregionalny. Najsłabsze powiązania z obszarami otaczającymi spośród miast wojewódzkich, wyrażające się w zakresie zarówno zasięgu przestrzennego, jak i skali relacji wykazują Gorzów Wielkopolski oraz Opole [Heffner 2011, s. 27-31]. Badania przestrzennego zasięgu konkretnych wymiarów powiązań także wskazują, że powiązania o skali regionalnej cechują spośród badanych obszarów miejskich tylko Wrocław, a pozostałe zamykają się w skali subregionalnej i lokalnej. Sytuacja taka zachodzi np. w wypadku dojazdów do i z pracy [Ilnicki, Michalski 2015, s. 60-64]. Przepływy pracujących między miastami będącymi centrami obszarów funkcjonalnych wskazują na kształtowanie powiązań sieciowych głównie w skali lokalnej. Jest to widoczne zarówno w sytuacji, w której miasta są źródłami dojazdów do pracy, jak i w sytuacji, gdy chodzi o przepływy między miastami [Ilnicki, Michalski 2015].

Innym wymiarem powiązań sieciowych jest współpraca różnych podmiotów uczestniczących w rozwoju lokalnym i regionalnym. Kmieć i Wrana [2011] zwracają uwagę, że tworzenie różnego rodzaju sieci może być procesem spontanicznym lub przybierać formę działań zaplanowanych, sterowanych przez konkretny podmiot lub grupę podmiotów. W przypadku badanych miejskich obszarów funkcjonalnych procesy te są sterowane i wynikają z konieczności zinstytucjonalizowania współpracy. W praktyce w badanych obszarach funkcjonalnych współpraca jest realizowana $\mathrm{w}$ dwóch formach, $\mathrm{tj}$. stowarzyszeń i porozumień. Stowarzyszenie jest w relatywnie wysokim stopniu zinstytucjonalizowane, ale umożliwia szeroką współpracę różnych podmiotów tworzących związek ZIT. Daje możliwość włączania administracji różnych szczebli, a także ma kompetencje większe niż tylko dotyczące wyboru projektów [Ratusznik 2013, s. 43]. Porozumienie jest znacznie mniej zinstytucjonalizowaną formą, a jego istotą jest przejęcie przez jedną z gmin obowiązku wykonywania zadań publicznych w imieniu pozostałych. W przypadku ZIT miejskich obszarów funkcjonalnych rolę taką z reguły odgrywa miasto centralne, które przyjmuje funkcję lidera całego porozumienia. Wyznaczenie lidera może spowodować uzależnienie realizacji ZIT od tego miasta, dlatego w razie zawarcia porozumienia konieczne jest właściwe wyważenie interesów wszystkich gmin uczestniczących w ZIT oraz wysoki poziom zaufania i umiejętności współdziała- 
nia. Odrębną kwestią jest włączenie współpracy innych niż władze samorządowe aktorów rozwoju, np. przedsiębiorców, NGO czy mieszkańców. Analiza strategii ZIT badanych jednostek daje podstawy, by sadzić, że taka współpraca zaistniała w każdym z obszarów funkcjonalnych. Jednakże trudno ocenić jej skalę, a także trwałość.

\section{Podsumowanie}

Traktując spójność terytorialną zarówno jako stan, jak i proces rozwoju regionalnego, można uznać, że miejskie obszary funkcjonalne wykazują związek z jej kształtowaniem. Istota i cele powołania miejskich obszarów funkcjonalnych oraz wdrażanych w ich obszarze strategii ZIT wskazują na kreowanie rozwoju policentrycznego opartego na wykorzystaniu zasobów wewnętrznych, uwzględniających sieciowe powiązania w układzie ponadregionalnym i regionalnym. Można zatem stwierdzić, że kształtowanie spójności terytorialnej przez rozwój miejskich obszarów funkcjonalnych wpisuje się w model polaryzacyjno-dyfuzyjny polityki rozwoju. Obecnie miejskie obszary funkcjonalne stanowią wyraźne bieguny rozwoju społeczno-gospodarczego i dotychczas podejmowane działania nie zniwelowały dysproporcji rozwojowych między nimi a pozostałą częścią regionów. Praktyka funkcjonowania miejskich obszarów funkcjonalnych wskazuje na niedoskonałości w zakresie wspólnoty celów rozwoju poszczególnych jednostek lokalnych z obszarami funkcjonalnymi, co oznacza w praktyce niedostosowanie zakresu merytorycznego projektowanych zadań do wspólnych potrzeb rozwoju jednostek terytorialnych. $Z$ tego faktu może wypływać wniosek, iż główną przesłanką tworzenia obszarów funkcjonalnych jest możliwość pozyskania środków wsparcia, co wskazywałoby na jednorazowość współdziałania. Taka sytuacja nie jest jednak zgodna z koncepcją spójności terytorialnej. W celu poprawy tej sytuacji postuluje się przede wszystkim uwzględnianie zasady konsensusu i partnerskiej współpracy gmin, a także ukierunkowanie działań na tworzenie warunków do rozprzestrzeniania się procesów rozwojowych. Aby można było minimalizować skalę zróżnicowania wewnątrz- i międzyregionalnego oraz stymulowanie sieci powiązań, konieczne jest budowanie kanałów wymiany towarów, ludzi i informacji między miejskimi obszarami funkcjonalnymi a ich zapleczem. Miejskie obszary funkcjonalne można traktować jako jednostki, które polaryzując rozwój, podnoszą swoją konkurencyjność, ale przy jednoczesnym tworzeniu warunków do rozprzestrzeniania się ich oddziaływania na obszary otaczające.

\section{Literatura}

Adamczyk-Łojewska G., 2011, Problemy konwergencji i dywergencji ekonomicznej na przyktadzie krajów Unii Europejskiej, w tym Polski, Ekonomia 4(16), Wydawnictwo Uniwersytetu Ekonomicznego we Wrocławiu, Wrocław, s. 57-76. 
Bronsztejn S., 1974, Ekonomika i planowanie regionu. Materiaty do nauczania, Wydawnictwo Uniwersytetu Wrocławskiego, Wrocław.

Domański R., 1993, Gospodarka przestrzenna, PWN, Warszawa.

Greta M., Tomczak-Woźniak E., 2013, Problem spójności w nowej polityce regionalnej UE na lata 2014-2020, Optimum: Studia Ekonomiczne, nr 4(64), s. 3-12.

Heffner K., 2011, Funkcje metropolitalne stolic województw Polski Zachodniej, Ekspertyza, Opole.

Heffner K., Gibas P., 2015, Obszary funkcjonalne i ich zwiąki z zasięgiem oddziaływania ośrodków subregionalnych (na przykładzie województwa opolskiego), Studia Miejskie, t. 18, Wydawnictwo Uniwersytetu Opolskiego, Opole, s. 10-23.

Hellwig Z., 1968, Zastosowanie metody taksonomicznej do typologicznego podziału krajów ze względu na poziom ich rozwoju oraz zasoby i strukturę wykwalifikowanych kadr, Przegląd Statystyczny, R. XV, z. 4, GUS, s. 307-327.

Kmieć T., Wrana K., 2014, Miasto społecznych powiazań sieciowych przestrzeniq nowej gospodarki, Studia Ekonomiczne. Zeszyty Naukowe Uniwersytetu Ekonomicznego w Katowicach, nr 187, Katowice, s. 171-181.

Koncepcja Przestrzennego Zagospodarowania Kraju 2030, 2012, Ministerstwo Rozwoju Regionalnego, Warszawa.

Krajowa Polityka Miejska 2014 (projekt, wersja I), marzec, Ministerstwo Infrastruktury i Rozwoju, Warszawa.

Krajowa Strategia Rozwoju Regionalnego 2010-2020. Regiony, miasta, obszary wiejskie, 2010, Ministerstwo Rozwoju Regionalnego, Warszawa, 13 lipca 2010.

Kuciński K., 1994, Geografia ekonomiczna. Zarys teoretyczny, Szkoła Główna Handlowa, Warszawa.

Kuźnik F., 2015, Miejskie obszary funkcjonalne a polityka miejska, Studia Ekonomiczne. Zeszyty Naukowe Uniwersytetu Ekonomicznego w Katowicach, nr 250, Katowice, s. 7-24.

Noworól A., 2015, Uwarunkowania, zasady i instrumenty nowego paradygmatu polityki regionalnej, [w:] Stec M., Bandarzewski K. (red.), Rozwój regionalny - instrumenty realizacji i rola samorządu województwa, Lex a Wolters Kluwer business, Warszawa, s. 13-27.

Płażek S., 2015, O instrumentach prawnych województwa samorządowego dla realizacji polityki regionalnej w dziedzinie transportu zbiorowego i dróg publicznych, [w:] Stec M., Bandarzewski K. (red.), Rozwój regionalny - instrumenty realizacji i rola samorządu województwa, Lex a Wolters Kluwer businnes, Warszawa s. 166-186.

Polski J., 2015, Spójność terytorialna jako podstawa polityki regionalnej, Prace Naukowe Uniwersytetu Ekonomicznego we Wrocławiu, nr 392, Gospodarka regionalna w teorii i praktyce, Wrocław, s. $73-80$

Programowanie perspektywy finansowej 2014-2020. Umowa Partnerstwa, 2015, Ministerstwo Rozwoju, Warszawa, grudzień.

Ratuszniak I., 2013, Ekspertyza. Realizacja Zintegrowanych Inwestycji Terytorialnych w Polsce, Centrum Doradztwa i Rozwoju Kompetencji, Wrocław, styczeń.

Rozporządzenie Parlamentu Europejskiego i Rady UE nr 1301/2013 z 17 grudnia 2013 r.

Sagan I., 2009, Czym sq i jak funkcjonują dzisiejsze regiony Polski?, [w:] Szomburg J. (red.), Jak uczynić regiony motorami rozwoju i modernizacji Polski, Polskie Forum Obywatelskie, nr 19, Gdańsk.

Smętkowski M., 2010, Konwergencja międzyregionalna w europejskich makroregionach metropolitalnych, Studia Regionalne i Lokalne, nr 2, Wydawnictwo Naukowe Scholar, Warszawa.

Stanowisko Rządu Rzeczpospolitej Polskiej do Komunikatu Komisji do Rady, Parlamentu Europejskiego. Komitetu Regionów i Komitetu Ekonomiczno-Społecznego Zielona Księga w sprawie spójności terytorialnej, MRR Warszawa, 2009.

Szafranek E., 2015a, Zintegrowane inwestycje terytorialne jako narzędzie wspierajace ksztaltowanie centrów rozwoju regionalnego, Rozwój Regionalny i Polityka Regionalna, nr 32, Wydawnictwo UAM, Poznań s. 81-94. 
Szafranek E., 2015b, Zintegrowane inwestycje terytorialne jako narzędzie budowy potencjatu obszarów funkcjonalnych. Przykład Kędzierzyńsko-Kozielskiego Subregionalnego Obszaru Funkcjonalnego, Prace Naukowe Uniwersytetu Ekonomicznego we Wrocławiu, nr 392, Gospodarka regionalna w teorii i praktyce, Wrocław, s. 109-118.

Szafranek E., 2016, Warunki zamieszkiwania w miejskich obszarach funkcjonalnych $w$ Polsce, Studia Miejskie, t. 21, Wydawnictwo Uniwersytetu Opolskiego, Opole, s. 153-166.

Szlachta J., 2011, Spójność terytorialna traktatowym wymiarem polityki strukturalnej UE, Prace i Materiały Instytutu Rozwoju Gospodarczego, nr 85, Szkoła Główna Handlowa, Warszawa, s. 191-214 .

Szlachta J., Zaucha J., 2010, A new paradigm of the EU regional development in the context of the Poland's National Spatial Development Concept, Institute for Development, Working Papers, no. 001/2010.

Ustawa z dnia 11 lipca 2014 r. o zasadach realizacji programów w zakresie polityki spójności finansowanych w perspektywie finansowej 2014-2020, art. 30, tekst jednolity, na podstawie DzU z 2014 r., poz. 1146, z 2015 r., poz. 378, 1130, 1240, 1767.

Zagrzejewska M., 2014, Spójność terytorialna - wyzwanie dla badań statystycznych, [w:] Zaleski J. (red.), Rozwój statystyki regionalnej w kontekście potrzeb informacyjnych polityki spójności. Nowe podejście do przestrzeni, Biuletyn KPZK PAN, z. 255, Warszawa.

Zaucha J., Brodzicki T., Ciołek D., Komornicki T., Mogiła Z., Szlachta J., Zaleski J., 2015, Terytorialny wymiar wzrostu i rozwoju, Difin, Warszawa. 